\title{
All Work, No Play ... : Representations of Child Labour in Films of the First World War
}

\section{Stella Hockenhull \\ University of Wolverhampton}

During the First World War, even though cinema was still in its infancy, it was seen as a viable tool for propagandist purposes. Furthermore, despite the domination of battle scenes and fighting at the front, a number of Home Front films were also produced to encourage patriotism and to advertise the effort required by the populace to support the troops. ${ }^{1}$ Indeed, Home Front newsreels were seen by the Government as mobilising useful moral support through nationalism, and, notably, a number featured children in their campaign. However, unlike preceding imagery of childhood, particularly that which had dominated the work of film directors such as Cecil Hepworth (1874-1953), these films did not depict them as embodiments of innocence and in need of protection, nor were they sentimentalised or represented as victims. $^{2}$ Instead, propaganda cinema of the First World War displayed infancy and youth in military style and as willing individuals ready to serve the nation; this was achieved by detailing their day to day activities in which they were seen as capable, and physically able to help with important tasks such as animal husbandry and food production. Indeed, depictions of children standing in line and operating in perfunctory fashion were habitually displayed, rather than engaged in play activities. and this chimed with the work of artists of the period, and contemporaneous and modernist art movements such as Vorticism. ${ }^{3}$ One such example, Even Children Help (1917), shows a group of schoolchildren working the land in an orderly and 
mechanistic way, and Children Grow Vegetables (1914-18) is comprised of shots of disciplined adolescent gardeners, these children dedicated to their task, and demonstrating the correlation between food and survival. This essay analyses the representation of children in documentary cinema of the First World War. It suggests that, rather than adopting sentiment which might evoke emotion and mobilise protests, the films were more pragmatic, deploying a more modernist style in keeping with the predominating 'structure of feeling' of that period which aimed at conscripting children for the war effort. The essay is divided into sections: the first part demonstrates the labour shortages and requirement to grow more food during the First World War thus contextualising the need for the official mobilisation of film for propaganda, as well as demonstrating the requirement for children to join the campaign. The second section examines a number of newsreel documentaries within the context of contemporaneous visual culture.

\section{Labour Shortages and the Food Campaign}

The scarcity of food became apparent early on in the war, although the real problem commenced prior to 1914 when shortages had arisen as a result of an increase in town dwelling resulting in a move from an agrarian to an industrial society in the late nineteenth century. Britain, therefore, had already experienced an agricultural depression and subsequently a collapse in food prices, and therefore relied heavily on imports; staples such as sugar, grains (in particular wheat) and meat were essential for the survival of this growing urban nation. ${ }^{4}$ By the outbreak of war, the government realised the need to increase its own domestic supplies while simultaneously safeguarding imports from naval attack. At this time, the Prime Minister, Herbert Asquith, established a Cabinet Committee on Food Supplies with 
the aims of protecting the national food store as well as supplying the nation with provisions at minimal cost. By 1917, however, the situation was serious, particularly because there had been a severe decline in harvest and potato crops during the earlier part of the period of conflict. Furthermore, animal husbandry was threatened by labour shortages, and it was necessary for all those able and available to help with these tasks. Food scarcity was associated with a paucity of agricultural labour which had occurred as a result of ever increasing military recruitment resulting in a depleted agricultural work force, particularly of trained men. ${ }^{5}$ As a consequence, from May 1915 onwards, the War Office forbade the further enlistment of skilled farm workers whose presence on the land was seen as essential as a leading force, their remit to instruct new recruits. Moreover, the replacement of the less experienced agricultural labourers necessitated enlistment from other sources including women, school children (during their school holidays), and prisoners of war. ${ }^{6}$ Recruitment appeals to encourage women to engage in animal husbandry and farm work were set up by War Agricultural Committees, a drive which the Women's Branch of the Board of Agriculture co-ordinated from the beginning of 1917. In addition, discussions were held about the contribution that child labour could make to the war effort through various activities such as manufacturing work, including munitions depots, but particularly food production. To achieve this, it was deemed necessary to reduce the school-leaving age, although Asquith was reluctant to instigate this, or to include children in his recruitment campaign. Parliamentary debates on this subject had begun as early as 1914, and eventually it was decided that the school-leaving age could be lowered in rural areas; 14 years old and above was considered an appropriate benchmark for child labour. ${ }^{7}$ 
The inclusion of children as part of the work force in the First World War caused much dispute, although it was regarded as crucial to replace the conscripts who had previously worked the land with whatever labour was now obtainable. Asquith's consent relied on fair remuneration and conditions of employment exemplified in a Parliamentary debate which took place in early 1915, and worth quoting at length:

I think myself that the withdrawal of children from school for employment in this way is to be regretted - if the need could be met by the unemployed who are at the disposition of the Labour Exchanges ... If child labour is to be resorted to, I think it ought to be resorted to in a national emergency, subject to the conditions clearly laid down by my right hon. Friend the President of the Board of Education a week or two ago ... The first is that the local authorities should see that every effort is made for the wages to be reasonable before they entertain the idea of relieving children from school attendance. The next condition is that there is no other form of labour practically or immediately available for the work. The last condition is that the employment should be of a light character, suited to the capacity of the child, and that it should be clearly understood that it is not to extend beyond the emergency with which we are for the time being, or shall be during the continuance of the War, confronted ... I should be very sorry if the idea were to go forth that there is going to be anything like a large resort to child labour in agriculture. It is an emergency thing, an exceptional thing, a thing which ought to be circumscribed in every possible way, and ought never to be resorted to unless the local authorities are satisfied that neither by the operation of the Labour Exchanges, nor by the increased employment of female labour, the gap cannot be made good. ${ }^{8}$

It was proposed that a reduced school-leaving age might be more appropriate for children in rural areas only because, as the Rt. Hon. Mr Long noted, a boy can easily fill the place of a man in certain areas such as agricultural work:

All I can say is, that I suppose boys vary as between different parts of the country, as they certainly do as between each other, because if a boy is carefully selected and properly supervised, he is a very valuable addition for certain kinds of labour. For instance you are urging the agricultural industry to increase the production of corn. To do that you must plough up land and you must harrow it. For a great deal of the land of the country which will produce the best wheat, you must have more than one person to work the plough. If you are going to use a man to do a boy's work, that is to say the leading of the horse, you will require two men instead of a man and a boy, and you are going to attempt something which will be impossible, because you cannot get the men. 
Thus, the notion that children could step in for adults, particularly where light work was involved, was accepted. Nonetheless, with the fear of child exploitation, and the observance of the necessity for a good education, adolescents were to remain at school until the age of 14 for the time being. By 1916 this situation had changed. A coalition government led by David Lloyd George was formed and this created the County War Agricultural Committees which was responsible for national food production from 1917 until the end of the war. ${ }^{10}$ Despite the ongoing concern over child labour, this was over-ridden by alarm over labour shortage leading to a move towards even younger children helping on the land. In a Parliamentary debate in May 1916, Colonel Charles Yate, an ex soldier himself, expressed his disquiet over the forthcoming hay harvest. Yate was a rural Shropshire man, and he believed that agriculture should take priority at whatever cost. Requesting that not only pensioners aid in the process, but also school children from as young as 12 upwards, he conveyed his fears and advice as follows:

The hay harvest is coming on, and I hope some steps will be taken to put an end to these difficulties and that we shall be able to get an order when there are a large number of soldiers in any particular neighbourhood to assist in the harvest without reference to the War Office or to anybody else. I hope the right Hon. Gentleman will do something to allow an old-age pensioner who can earn a few shillings haymaking to do so without affecting his pension. One or two references have been made to the employment of child labour, and a great deal has been said not to allow children to leave school for the harvest. I have not the slightest hesitation in saying that I hope every boy over twelve years of age will be allowed to leave school during the next hay harvest to do what he can to get it in. I do not say this in reference to any boy under twelve, but if he is over twelve years of age he can help in the hay harvest. ${ }^{11}$ 
To deal with the problem adolescents as young as 12 were recruited in rural areas, a situation which lasted until the end of the war. As Richard Van Emden and Steve Humphries suggest,

There was a big exodus of village children from their classrooms, as many thousands were officially sanctioned to help the war effort ... Every pair of hands was welcomed in the fields, most of those exempted being the sons and daughters of agricultural labourers. Even those country children who continued to attend school found that at certain times of the year they would be called from their classroom to do war-related work. ${ }^{12}$

In sum, during the First World War children were employed not only in factories, but also on farms and, in some situations, a child's earnings could supplement a family's income. ${ }^{13}$ In sum, by mid point in the war, it was deemed essential that children be recruited for the war effort and campaigns were set up to encourage youth involvement. This included newsreels shown at the cinema, and exhibited simultaneously to the fiction films, shown as part of the propaganda drive.

\section{Propaganda and Cinema during the First World War}

Film formed a main component of the government's drive to gain support for its campaign and towards a patriotic propagandist message, but not until nearly half way through the war. Prior to this, from 1914 onwards, the British people were optimistic, and motivated by official and unofficial reportage, they united for the cause. Indeed, initially the press had commenced an onslaught of unofficial propaganda concerning the immorality of the enemy, and this was bolstered by a large scale government campaign to influence opinion both at home and abroad. What began as the National Insurance Commission set up in 1914 under the leadership of Charles Masterman, was replaced in 1917 by the Department of 
Information (DoI) which eventually became the Ministry of Information (MoI). Working alongside the DoI, the National War Aims Committee (NWAC) was the brainchild of the novelist John Buchan. He was concerned that there was little provision made for propaganda in Britain and suggested a series of lectures and addresses leading to its formation in August 1917. Set up to deal with domestic propaganda, the organisation's aims were defined as 'strengthening national morale, combating pacifism, spelling out the advantages of an Entente peace, explaining the meaning of a German peace, inspiring war workers at home, and encouraging unity by stifling party and class dissension'. ${ }^{14}$ Methods deployed included the dissemination of articles and pamphlets, the NWAC working directly with high street companies such as WH Smith to produce and distribute them. Poster, cartoon and postcard images all aimed to disseminate a specific message and public meetings and talks were also held, often paid for by the organisation.

As noted, in terms of film, from as early as 1916 onwards, the benefits of cinema as an important propagandist tool had been realised. ${ }^{15}$ This medium had, while still in its infancy and prior to the First World War, appropriated a working class audience, and cinema-going had become a widespread pastime. ${ }^{16}$ During wartime, therefore, it presented itself as an ideal venue to propagate doctrine. ${ }^{17}$ Its popularity expanded during the period of conflict, particularly as a means of escapism from the horrors of the battlefield, and apart from showing fiction films via American imports, the advantage of documentary cinema was also discovered. ${ }^{18}$ This took the form of either lengthy depictions of battle scenes or the shorter newsreels which contained forthright and pithy messages which were factual in content. ${ }^{19}$ Indeed, for much of the early part of the twentieth century the population saw the news at the cinema 
because newsreels were a typical element of the overall entertainment programme. With the lengthier battle scenes, if possible they should be shot on the front line, but failing that, footage of military training programmes, feeding the troops and the industry required to supply the war effort sufficed. ${ }^{20}$ The shorter silent newsreels were disparate in content and contained on one single reel of film; these were very much in the hands of the British newsreel company, Topical Budget, relaunched in May 1917 as The War Office Topical Budget, although French companies such as Gaumont and Pathé also created brief, specially produced documentaries for the screen. A series of weekly newspaper-type shorts lasting between two and ten minutes long, known as 'tag' films, were screened between feature length films in the cinema, and were seen by about ten million people, and intended for home audiences and described as "a short film, taking about two minutes to show, and embodying, usually in story form, some useful moral such as "Save Coal" or "Buy War Loan", ${ }^{21}$ The government also set up its own studios using professional filmmakers and the short propaganda films included, amongst others, campaigns to aid female recruitment to the Women's Land Army (WLA), as well as to encourage food economy. In 1916, the War Office Cinematograph Committee was established, chaired by Lord Beaverbrook, Britain's first Minister of Information, and this organisation cooperated with the DoI's cinema division resulting in a number of regular bi-weekly newsreel films shown in cinemas. With national food shortages now becoming a major issue, and with growing political and social unrest from the working class, campaigns began which 'switched the emphasis from elite, indirect propaganda to direct mass propaganda ... they directly targeted public opinion itself $^{22}$ 
It was believed at the time that the films played a part in maintaining home front morale. As Beaverbrook claimed, '[t]he Topical Budget shown in every picture palace was the decisive factor in maintaining the morale of the people during the black days of the early summer of $1918^{,}{ }^{23}$

As noted, children were deemed essential in supporting industry and working the land, and one way to reinforce this was through visual imagery. This necessity for child recruitment meant that the government could ill afford their sentimentalisation and, as a result, images of childhood in films of the First World War avoided this, instead demonstrating their military prowess. This type of representation contradicted Victorian attitudes to childhood, particularly in painting and literature where, in general, children were seen as innocent and untainted. As Kimberley Reynolds points out, in fiction, 'childhood came to be associated with a set of positive meanings and attributes, notably innocence, freedom, creativity, emotion, spontaneity and, perhaps most importantly for those charged with raising and educating children, malleability, ${ }^{24}$ Childhood innocence was rooted in Romanticism, and the idea existed that children should be protected from the adult world and permitted to enjoy their youth. This coincided with various commissions leading to an assortment of laws passed protecting children at work, at school and in the home. ${ }^{25}$ As a result, 'writers and artists began to produce increasingly sentimentalized images of children, emphasising their angelic, adorable qualities'. ${ }^{26}$ Poets such as William Blake and William Wordsworth saw childhood as akin to godliness. In literature, Charles Dickens, Lewis Carroll and E. Nesbitt portrayed adolescence as a time of playfulness and purity, and likewise in painting and illustration childhood was represented as a period of reverence. Paintings such as 
Bubbles (Millais 1886) showed a wide-eyed boy gazing upwards in angelic pose, his face surrounded by blond curls and illuminated as a sign of his innocence. ${ }^{27}$ By the turn of the century, such representations were superseded by various styles which favoured a more modernist and less precise approach. Attention to detail and accuracy was replaced by leanings towards a dynamic art which celebrated the machine age although, in general, these images were not of children. One such movement, Vorticism, came into existence in 1914 as a response to the European art movements of French Cubism and Italian Futurism. Given its name by the poet, Ezra Pound (1885-1972), it was led by the writer and artist, Wyndham Lewis (1882-1957) and emanated from an exhibition entitled An Exhibition of the Work of English PostImpressionists, Cubists and Others held in Brighton in December 1913 to January 1914. ${ }^{28}$ Lewis's contribution, entitled 'The Cubist Room' was described as 'revolutionary art', and featured the painters, Bernard Adeney, David Bomberg, Jacob Epstein, Jessie and Frederick Etchells, Fanny Everleigh, Cuthbert Hamilton, Christopher Nevinson and Edward Wadsworth. In January 1914, the philosopher and critic, T.E. Hulme (1883 -1917) delivered a lecture where he distinguished between the representational art of the past, which he deemed 'organic' and the abstract, geometric and mechanistic art of the future. ${ }^{29}$ The former was 'safe, familiar, and loved on the one hand, and adventurous, dangerous and shocking on the other', this notion thus chiming with the onset of war. ${ }^{30}$

The visual characteristics of Vorticism varied between the artists, yet the creative styles may be mapped on to other thought processes occurring during the First World War in what Marxist historian, Raymond Williams, terms a 'structure of feeling, ${ }^{31}$ Williams explains this concept as a connection between the prevailing 
mood at any one given time and the dominant ideas that are represented in various forms of cultural texts. This, the scholar suggests, involves 'the continuity of experience from a particular work, through its particular form, to its recognition as a general form, and then the relation of this general form to a period' ${ }^{32}$ According to Williams, a 'structure of feeling' is not necessarily official discourse but also popular, cultural and literary responses to contemporary events. However, it is only in retrospect that the generalised emotion and attitudes of a society are identified in line with a uniformity of ideas in cultural forms such as painting, literature, and film. Indeed, the early twentieth century has been heralded as a pivotal point in cultural history with modernism at the forefront of literature and the visual arts and a number of official war artists were also operating in a similar style suggesting that these ideas were established and acknowledged during this period. One such example, Christopher Nevinson, had lived in Paris prior to the war working with both Marinetti and Severini, two Futurist artists. As Meirion and Susie Harries suggest, these artists "welcomed war as an irresistible force for good - the "hygenics" of the world' ${ }^{33}$ Nevinson took the opportunity in his work to follow the same pathway: as he pointed out, 'our Futurist technique is the only possible medium to express the crudeness, violence and brutality of the emotions seen and felt on the battlefields of Europe' ${ }^{34}$ He had contributed to the Brighton exhibition of 1913/14 and many of his works produced early on during the First World War were based on his experiences as an ambulance driver in France 'using his own mongrel blend of Futurist and Cubist techniques'. ${ }^{35}$ His images, such as Returning to the Trenches (1914) and La Mitrailleuse (1915) went on public display at the Leicester Galleries in 1916 in a one man show, and were popular with critics and the public because they were 'intelligible and unintimidating to the layman'. ${ }^{36}$ Returning to the Trenches shows 
the marching troops as machine-like, forceful and dynamic and thus dehumanising them, and, similarly, La Mitrailleuse reduces the soldiers to a series of angular shapes whereby they appear almost mechanised and homogenous, blending with the machine guns that they carry. When he later became an official war artist in 1917 he was one of the first artists to paint aerial subjects from inside a plane. ${ }^{37}$ While Vorticism and a modernist visual style had far reaching effects in the art world during the First World War it is tenuous to suggest that the newsreel filmmakers operating during this time were modernists, or that they consciously decided to create images dehumanising their subjects. However, links might exist. Official war artist, Augustus John, was asked by Lord Beaverbrook to design a poster to advertise the newsreels of War Office Official Topical Budget. This consisted of a soldier on the march looking upwards with a blank section left for the name of the film. While it was never used, the soldier's figure, set against three broken branches of trees, appears mechanistic and angular, thus evoking a modernist approach suggesting that this type of visual style prevailed. ${ }^{38}$ Nonetheless, the requirement to engage children for the cause, and the necessity to feed the nation was strong and the sentimentality had no place in documentary films.

Whereas WLA films were aimed at conscription, those that featured children were less persistent in their crusade, tending to document their work as useful for military support and intervention. In fact, rather than directly appeal for child labour, they showed them willingly hard at work on the land as part of the drive to grow food and, in turn, offered a celebration of armed forces training. Furthermore, unlike the previous decade's proclivity to depict children in a sentimental manner, and despite the occasional use of medium shots to portray their facial expressions, childhood is 
not romanticised in these films. ${ }^{39}$ In The Smallest Soldier in the British Army (British Pathé 1917), for example, a young boy is seen handling a bayonet and behaving in military fashion mimicking the infantry. The film opens with a medium shot of the boy sternly observed by a trained soldier whose bayonet is raised above his left shoulder. Both are shown in the frame together, and the child is not prioritised. Similarly clad in full military uniform the child stands, shoulders back and to attention, before assembling his bayonet and practising the types of procedures associated with spearing an enemy. He takes no instruction from the watching soldier, appearing to understand fully the procedures required of him. Initially, having assembled the weapon, he takes one step forwards in a rigid pose, aggressively thrusting his bayonet towards the unseen enemy. He then directs it three more times before carefully advancing a number of paces as though to complete the slaughter of his foe. Adopting the same strategy in reverse, he brusquely withdraws the bayonet to his side and again stands to attention. Notably, the camera does not focus on the child's face to invoke sentiment, nor does the boy look at the camera. Instead he behaves in a mechanical fashion and is depicted as controlled, aggressive and heroic - all attributes associated with adult behaviour, hence desirable for the military.

If The Smallest Soldier in the British Army seems a shocking example of encouraging children to engage in aggressive behaviour, then this attitude was also actively encouraged through elements of play. Miniature soldier uniforms and model weaponry were marketed and on sale at toy shops to promote military imitation, and the manufacture of armed forces paraphernalia encouraging children to fight for the cause was, as George Robb notes, 'propaganda [which] was 
surprisingly violent considering that it was aimed at very young children'. ${ }^{40}$ As he points out, this was a deliberate government ploy: 'Masterman and later John Buchan at the Department of Information subsidized propaganda directed at children, including James Yoxall's Why Britain Went to War: To the Boys and Girls of the British Empire (1914), ${ }^{41}$ Furthermore, and a point noted by Elizabeth Galway, this was also the situation in children's literature which championed courage in chorus with oppression: as she suggests, 'the underage boy fighter is a potent image of masculinity and heroism that can simultaneously embody the victimization of children'. ${ }^{42}$

While The Smallest Soldier in the British Army promotes child participation in fighting activities, there was never any intention that children should serve at the front. Nonetheless, by 1916 the utilisation of children as part of the work force in support of the military campaign was common practice in Britain, particularly in rural areas. Indeed, the needs wrought from the conflict had brought about a process named 'half-timing' where, particularly in agricultural areas, children worked half of their time at school and the other half in the fields. This is demonstrated in the British Pathé forty seven second film entitled Even Children Help (1917), which shows a group of children employed toiling on the land. Listed as 'schoolchildren helping on the land in Dunstable', the film shows them enthusiastically lining up in orderly fashion and raising their implements over their left shoulders in mock military mode. In a similar vein to Nevinson's figures, they appear angular and programmed, thus losing any individuality. Certainly, they do not appear as innocents, instead emerging as capable and skilled individuals rather than the children that they are. As Galway argues, albeit in terms of World War One 
literature, 'in times of military need, images of child innocence, passivity, and naivety are often replaced by depictions of children as ready, willing, and able to serve their nation'. ${ }^{43}$ In this film, the camera pans across the figures of mixed gender children, some easily under 12 years old; this suggests that, regardless of age and sex, all must aid with the war effort. Dressed in hats and coats, the adolescents face the camera, females at the front, their expressions grave and seemingly ready to approach their task. The girls carry rakes, and the boys arm spades for the heavier work. Indeed, an edit to a group of five boys digging a trench to plant vegetables confirms this commitment; they too avoid looking at the camera and work with exactitude and care as they solemnly undertake their 'duty'. This sequence is followed by an image of two girls hoeing between the plants; it is a cold day and the trees are bare suggesting early spring, and inhospitable weather. The difficulties of the task are thus not erased, and the job not made to look easy, although all youths appear uncomplaining in the line of duty. As one ten year old girl who worked the land remembers, 'We did it because the men had all gone to war, we did it to help win the war. It was a terrible time. They were good men and they were killed. We wanted to do our bit to help'. ${ }^{44}$ In Even Children Help, through their mechanistic and orderly behaviour, the viewer is primed to accept the notion that children are resourceful and respected members of society who can ably contribute to the war effort.

In Children Grow Vegetables (British Pathé), the children appear more middle class than those depicted in Even Children Help, and the setting is now inner city London rather than the countryside. Again, however, they are bent over their tasks sombrely undertaking arduous work, and the British flag flies in the background suggesting 
the requirement for patriotic duty. This obligation to serve the Empire was constantly reinforced and much effort was made during this period to engage children in this process.

Every Little Helps (British Pathé), another film reinforcing the notion that there exists a need for everyone to participate in the war effort, infers that even part time work or through leisure activities such labour is a bonus. The use of hedgerows for the provision of free food is highlighted, and blackberry picking is listed as one activity. Again the children are witnessed contributing to the endeavour in military style. Of all ages, they line up in an obedient and methodical fashion and comb the hedges for the fruit which, we are told, will be weighed in to make jam. A close-up of the produce indicates that the filmmaker is familiar with the use of this technique to create an appealing image, and the fruit is invitingly presented as that which can be gained free of charge. The children, nevertheless, are retained in medium shot, arguably to discourage sentiment and create distance, as to focus in on their faces enables spectator identification and empathy when clearly their tasks are arduous. ${ }^{45}$ As noted, it was an emotive issue to engage children in any form of work although the youngsters here are clearly supervised. A cut from the close-up image of the fruit to one of the boys planting vegetables, his head bent over as he digs hard, again shows how gruelling a task it is, yet suggests that they manually work as a team, an operation which will make some headway towards winning the war.

It was not only early school leavers that worked on the home front. More mature youths and teenagers also responded thus demonstrating solidarity. A distinct British youth culture had developed in the late nineteenth century co-ordinated by groups 
such as the Boy Scouts, Girl Guides and Naval Scouts. The aim of these factions was to encourage moral values, national pride and a commitment to Empire, and they later proved instrumental in marshalling young people to aid in the conflict. Many were given military style training at school and encouraged to feel part of the war: ${ }^{46}$ they patrolled coastal areas and acted as messengers, and their tasks were well documented in the films of the period. Fiction cinema had already presented the work of the Girl Guides in films such as The German Spy Peril (Haldane 1914), Guarding Britain's Secrets (Calvert 1914) and The Kaiser's Spies (Raymond 1914), and the growing demand for equality was nurtured to some extent particularly when the Guides eventually replaced the Scouts as messengers for military intelligence because they were perceived as more dependable and less disruptive. As James Chapman indicates,

The First World War provided girls with an opportunity to show that they could be as good as, if not better than boys. At the start of the war, Boy Scouts were employed as messengers at the London headquarters of Military Intelligence, MI5. But they were soon found to be "very troublesome. The considerable periods of inactivity which fell to their share usually resulted getting into mischief', stated MI5 report KV/49. ${ }^{47}$

Those girls working as messengers had to have signed permission from their parents and pledge with their honour that they would not read the documents. Girl Guides were also employed in the munitions factories from the age of 14 upwards, and, during the First World War children formed a major part of the factory workforce. In total, of its 40,000 workforce, the arms manufacturers at Woolwich Arsenal employed 6,500 children. 
The Boy Scouts Association was one of the first youth organisations to provide practical assistance to the British war effort. Their tasks included guarding telephone and telegraph lines, railway stations, water reservoirs or any location that might be militarily important. From late 1917, many Scouts assisted with air raid duties, including sounding the all-clear signal after an attack, and they were also trained in fire fighting. Correspondingly, Sea Scouts were part of the larger Scouting Movement and they operated as observers that stood watch on the coast in anticipation of German air attacks or a possible invasion. Furthermore, they were also enlisted to aid in food production and distribution. This type of activity is shown in a ten minute film entitled Mr Robert Middlemas's Food Production at Ilford (Ministry of Information 1918). The film opens with the caption that informs that Mr Middlemas has organised spare-time work for the men and boys of Ilford. He has set up shop in the centre of the town, and the film follows a mini narrative whence it is suggested that rabbits can be purchased here and bred for food. Scouts, we are informed, collect waste to use as pig fodder. Initially the boys are depicted in their uniforms pushing a cart around the streets to collect waste, before the next shot displays the animals that they feed. Men, women, Boy Scouts and Girl Guides are then shown cultivating the hospital grounds, and the film highlights one boy as a glowing example. Named as 'Ilford's champion digger', he is shown hard at work on the land. In the film, the children toil on allotments and Sea Scouts pick black fly off growing broad bean plants, pausing for their own meal alongside a makeshift tent. Thereafter, the Sea Scouts and Boy Scouts are shown collecting refuse from door to door for their pigs, and an inter title informs that the Ilford Boys Pig Club owns 10 breeding sows and 77 store and young pigs. This and other examples imply 
that such activities offer adventure, and they successfully conflate the images of the boys with that of the grown up soldier through their demeanour and attire. ${ }^{48}$

In all, while some attempt was made to protect children in the First World War by reducing the school age only where necessary, mainly in rural areas, they were still recruited to aid with the war effort. This was shown in short documentary propaganda films which rejected nineteenth-century sentiment prevalent in painting and literature. Instead, filmmakers opted for a more regimented style of representation in line, in some instances, with contemporary practices in the visual arts. Indeed, filmmakers shunned the use of close-ups which avoided identification with the children and thus evaded emotion and compassion. Instead, they were, more often than not, displayed en masse and military style hard at work. The First World War was a period of concern for the government, especially as the conflict gathered momentum, and the necessity for labour of any description in order to feed the nation was of primary importance yet went against the notion that children should be nurtured and protected.

\footnotetext{
${ }^{1}$ For example, films such as Britain Prepared (1915) and Battle of the Somme (1916). Cameramen would work at the front and send back footage for exhibition in Britain and around the world. See Nicholas Reeves 'Official British Film Propaganda' in Michael Paris (ed.) The First World War and Popular Cinema (New Brunswick, New Jersey, 2000), pp. 27-50.

${ }^{2}$ The nineteenth century witnessed a new conception of childhood as an innocent state to be shielded and prolonged. Hepworth's Rescued by Rover (1905) is a fiction about a kidnapped child rescued from an evil, gin-drinking gypsy. Similarly, many paintings of the period sought an emotion from the viewer to evoke nostalgia for the inevitably fleeting nature of childhood. See Lionel Lambourne, Victorian Painting (London, Phaidon Press 2003).

${ }^{3}$ Vorticism was the British response to French Cubism and Italian Futurism, and was given its name by the poet, Ezra Pound (1885-1972) and led by the artist, Wyndham Lewis (1882-1957). See Mark Antliff and Vivien Greene (eds) The Vorticists: Manifesto for a Modern World (Tate Publishing 2010).

${ }^{4}$ Avner Offer, The First World War: An Agrarian Interpretation (Oxford, Clarendon Press, 1989). Also, see Adrian Gregory, The Last Great War: British Society and the First World War (Cambridge, Cambridge University Press, 2008).

${ }^{5}$ Further emphasis was placed on agricultural food production. See Alan G. V. Simmonds, Britain and World War One (London, New York, Routledge, 2012), p. 209.
} 
${ }^{6}$ The shortage of farm labour was remedied in part by prisoners of war. See image German Prisoners of War: camp in England for non-commissioned officers and men (1917 IWM).

${ }^{7}$ Children (employment and school attendance) Bill. HC deb 20 February 1914 vol. 58 cc1292-367

http://hansard.millbanksystems.com/commons/1914/feb/20/children-employment-andschool\#s5cv0058p0_19140220_hoc_101 (Accessed 03/02/2015).

${ }^{8}$ CHILD LABOUR (AGRICULTURAL DISTRICTS) HC Deb 04 March 1915 vol 70 cc997-1046

http://hansard.millbanksystems.com/commons/1915/mar/04/child-labour-agricultural-

districts\#S5CV0070P0_19150304_HOC_317. (Accessed 02/10/2015).

${ }^{9}$ CHILD LABOUR (AGRICULTURAL DISTRICTS).HC Deb 04 March 1915 vol 70 cc997-1046

http://hansard.millbanksystems.com/commons/1915/mar/04/child-labour-agriculturaldistricts\#S5CV0070P0_19150304_HOC_317 (Accessed 02/10/2015).

${ }^{10}$ Members consisted of wealthy county landowners, farmers and agriculturalists. See Richard Van Emden and Steve Humphries, All Quiet on the Home Front (London, Headline, 2003), pp. 215-216.

${ }^{11}$ NATIONAL FOOD SUPPLY.

HC Deb 22 May 1916 vol 82 cc1831-952

http://hansard.millbanksystems.com/commons/1916/may/22/national-food-

supply\#S5CV0082P0_19160522_HOC_301. (Accessed 14/01/2016).

${ }_{12}$ Richard Van Emden and Steve Humphries, All Quiet on the Home Front: An Oral History of Life in Britain during the First World War (London, Headline Book Publishing, 2003), p. 273.

${ }^{13}$ Eventually, as a result of the lowered school-leaving age and coinciding with the end of the war, the Education Act was drawn up which introduced a number of reforms including the outlawing of employment of children under the age of 12. Furthermore, children were not allowed to work in mines, factories, workshops or quarries, and any entertainments in which they appeared would require a licence issued by the Local Education Authority.

14 Nicholas Reeves, The Power of Film Propaganda: Myth or Reality? (London, New York, Continuum, 2003), p. 21.

15 This was not only on film however. Women's weekly magazines such as Woman's World and Mother and Home focused on ideas for economy during wartime. The magazines included recipes and tips. See George Robb, British Culture and the First World War (Basingstoke, Palgrave, 2002), pp. 61-62.

${ }^{16}$ Its pricing policy undercut the theatres and music halls. See Reeves, 2003, p. 22.

${ }^{17}$ Nicholas Reeves, 'The Power of Film Propaganda - Myth or Reality?' Historical Journal of Film, Radio and Television, Vol. 13, Issue 2, (1993), pp. 181-201.

${ }^{18}$ See Gerard J. DeGroot, Blighty: British Society in the Era of the Great War (London, New York, Longman, 1996).

${ }^{19}$ Films such as Battle of the Somme (1916) premiered in August 2016 depicting trench warfare.

${ }^{20}$ Indeed, initially cameramen were sent out to film at the Front but very little was shot on the battlefields and, with threats of censorship, they soon returned to report the war from home. See Luke McKernan, Topical Budget (London, BFI Publishing).

${ }^{21}$ Rachel Low, The History of the British Film 1914-1918 (London, George Allen and Unwin Ltd., 1973), p. 37.

${ }^{22}$ See Philip M. Taylor, British Propaganda in the Twentieth Century (Edinburgh, Edinburgh University Press, 1999), p. 7; Stella Hockenhull, 'Everybody's Business: Film, Food and Victory in the First World War', Historical Journal of Film, Radio and Television Special Issue Vol. 35 No. 4. (2015), pp. 579-595. ${ }^{23}$ Quoted in A.J.P. Taylor, Beaverbrook (Hamish Hamilton, 1972), p. 144.

24 Kimberley Reynolds, 'Perceptions of Childhood' https://www.bl.uk/romantics-andvictorians/articles/perceptions-of-childhood (Accessed 1/03/2017).

${ }^{25}$ For example, in 1840, Lord Ashley helped set up the Children's Employment Commission which published Parliamentary reports on conditions in mines and collieries. In 1833 the Factory Act was passed and in 1867 the Workshops Act. See Marah Gubar, 'Representing Childhood: The Victorian Child c. 1837-1901' http://www.representingchildhood.pitt.edu/victorian.htm. (Accessed 19/02/2017).

26 Marah Gubar, 'Representing Childhood: The Victorian Child c. 1837-1901' http://www.representingchildhood.pitt.edu/victorian.htm. (Accessed 19/02/2017).

$\overline{27}$ This of course was contradictory and inconsistent with the cruelty and child labour which also occurred during this period.

${ }^{28}$ Pound used the term for the first time in April 1914 and defines the vortex as 'that point in the cyclone where energy cuts into space and imparts form to it ... the pattern of angles and geometric lines which is formed by our vortex in the existing chaos' in Philip Rylands, 'Introduction' in Mark 
Antliff and Vivien Greene (eds) The Vorticists: Manifesto for a Modern World (Tate Publishing 2010), p. 23.

${ }^{29}$ Robert Upstone, “"The Cubist Room" and the Origins of Vorticism at Brighton in 1913', in Mark Antliff and Vivien Greene (eds) The Vorticists: Manifesto for a Modern World (Tate Publishing 2010), p. 29.

${ }^{30}$ Philip Rylands, 'Introduction' in Mark Antliff and Vivien Greene (eds) The Vorticists: Manifesto for a Modern World (Tate Publishing 2010), p. 21.

${ }^{31}$ Raymond Williams, Drama from Ibsen to Brecht (Harmondsworth: Penguin ([1968] 1973).

${ }^{32}$ Williams, p. 9.

${ }^{33}$ Harries and Harries, p. 38.

34 in Harries and Harries, p. 38.

${ }^{35}$ Harries and Harries, p. 39.

${ }^{36}$ Harries and Harries, p. 39.

${ }^{37}$ It is worth noting that Vorticism was not the dominant style in painting during the First World War, although a number of artists painted in a modernist style. Examples include the brothers, Paul and John Nash, William Roberts, Henry Lamb and Stanley Spencer. Although Vorticism flourished during the war years, many abandoned this progressive style after the period of conflict. As James Fox suggests, "Art historians have traditionally seen this as a disappointing, if not disastrous, development: the war they have concluded, ended a promisingly radical moment in British art and produced in its aftermath an insular and reactionary period characterized by "stagnation", "uncertainty" and "retreat". See James Fox, British Art and the First World War 1914-1924 (Cambridge, Cambridge University Press). p. 6.

${ }^{38}$ See Luke McKernan, Topical Budget (London, BFI Publishing), p. 47.

${ }^{39}$ The use of the close-up was used from as early as 1910 for emotional purposes. See Paul Schrader, 'Game Changers: the Close-Up', Film Comment September, October (2014), http://www.filmcomment.com/article/the-close-up-films-that-changed-filmmaking/ (Accessed 30 November 2016).

${ }^{40}$ The London toy shop, Gamages, marketed war-themed toys such as tanks, ships, and toy soldiers. Board games based on battles such as 'From the Ranks to Field Marshal' rewarded players for heroic acts of battle. See Robb, p. 176.

${ }^{41}$ Robb, p. 176.

${ }^{42}$ Elizabeth A. Galway, 'Competing Representations of Boy Soldiers in WW1 Children's Literature' Peace Review: A Journal of Social Justice Vol. 24, Issue 3, (2012), 299.

${ }^{43}$ Galway, pp. 298-304.

${ }^{44}$ In Van Emden and Humphries, p. 276. The writer here was a middle-class child, but in reality a large number of children were exploited with many under-age children in full-time work. As Van Emden and Humphries suggest, 'As a rule, the younger the child in full-time work, the more desperate the family circumstances tended to be', p. 277.

${ }^{45}$ Although cinema was in its infancy, fiction films had begun to include the use of close-ups in their narratives. In East Lynne (Haldane 1913), for example, close-ups are shown of Isabel (Blanche Forsyth) to demonstrate her anguish demonstrating a familiarity with the significance of this type of shot for narrative motivation. Not only was this deployed to encourage spectator identification with adults, it had also been used to suggest childhood innocence, for example in many of Charlie Chaplin's early films.

${ }^{46}$ As George Robb points out, there was a wave of patriotic marketing directed at youth with military toys and board games. See Robb, (2002).

${ }^{47}$ James Chapman, A New History of British Documentary (London, Palgrave Macmillan, 2015), p. 12.

${ }^{48}$ Young people were also shown on the covers of popular periodicals such as The Boy's Own Paper and Young England which were filled with stories about youth military training. 